\title{
Effect of Short Term Temperature on Physiological Body Indices of Two Estuarine Venerid Clams Katelysiaopima and Meretrixmeretrix (Mollusca: Bivalvia)
}

\author{
V. M. Lagade* and D. V. Muley ${ }^{1}$ \\ Department of Zoology, Shri Yashwantrao Patil Science Mahavidyalaya, Solankur, Kolhapur \\ (Maharashtra), India -416 211. \\ 1'Department of Zoology, Shivaji University, Kolhapur (Maharashtra), India -416 004.
}

\begin{abstract}
In the present investigation, the physiological body indices like hepatopancreas index (HI), gonadal index $(\mathrm{Gl})$ and condition index (Cl) of two estuarine clams (Katelysiaopima and Meretrixmeretrix) were estimated after exposing to three experimental temperatures $\left(20,25\right.$ and $\left.35^{\circ} \mathrm{C}\right)$. In experimental design, both the clam species were exposed to selected temperatures for 192 hours (8 days) and during the exposures the body indices were determined at each 48 hours of interval. After exposing to experimental temperatures, in both the clams, all body indices like $\mathrm{HI}, \mathrm{Gl}$ and $\mathrm{Cl}$ were considerably declined $(p<0.001)$ after 192 hours of exposure. The highest decline in body indices has been noted particularly at high temperature $\left(35^{\circ} \mathrm{C}\right)$ followed by low temperature like $20^{\circ} \mathrm{C}$ and $25^{\circ} \mathrm{C}$. On the basis of obtained results, it confirms that, the gonadal index was closely related to hepatopancreas index and increment of condition index is directly associated with gonadal development. Relatively, M. meretrix species was more sensitive towards temperature change and it has been evident from the maximum decline in body indices than $\mathrm{K}$. opima. Hence, the quantitative analysis of body indices among clams might be useful in assessing the probable effect of short-term change in water temperature on physiological process.
\end{abstract}

Keywords: Physiological body indices, Clams, Hepatopancreas, Temperature.

\section{Introduction}

Coastal zones like estuaries, creeks, backwaters and lagoons are ecologically as well as economically important and are among those areas which strongly affected by global climate change (Laning et al., 2010). The environmental changes, affects the metabolic activities and biological performance of an organism, however the mechanism of action of environmental factors and their risks on marine ectothermal organisms that are not yet fully understood (Melzner et al., 2009; Portner, 2010).

Among environmental factors, temperature plays the crucial role in all facets of organisms life (Gillooly et al., 2001). To measure the environmental or temperature consequences, the behaviour and physiological alterations are considered as functional attributes to identify the stress. Generally, stress conditions cause energy limitation, which reduces the energy investment in to production hence, it will have the direct impact on the fitness of an organism (Laning et al., 2010).

Physiological fitness of an organism under various environmental stressor particularly temperature can be ascertained by assessing the physiological body condition indices like hepatopancreas index, gonad index and condition index. According to the literature, hepatopanceras and gonad are the major organs of invertebrate, which stored the reserve nutrients and these reserves are mobilized according to seasonal cycle (Galap et al., 1997; Lomovasky et al., 2004) or reserved 
nutrients of hepatopancreas are utilized for gonadal development (Sokolowicz et al., 2006). Condition index has been employed by various authors to determine the physiological activity like reproduction and growth ( $\mathrm{Li}$ et al., 2009; Mladineo et al., 2007; Celik et al., 2012; Li et al., 2011). Literature reported that, the condition index among bivalve species fluctuates by change in water temperature, food availability and season (Flores-Vergara et al, 2004; Delgado et al., 2004; Ojea et al., 2004; Orban et al., 2006).

Earlier, few authors have reported the effect of temperature on the condition index and gonad maturity of bivalves (Newell et al., 1982; Mac Donald and Thompson, 1985; Martinez and Perez, 2003). In recent, Suja and Muthiah, (2009) studied the synergistic effect of starvation and temperature on hepatopancreas somatic index, gonad somatic index and condition index of Marcia opima from Tuticorin Bay. Matias et al., (2008) documented the effect of temperature on condition index of Ruditapes decussates.

This attempt has been ascertained to detect the effect of short-term exposure of temperature on hepatopancreas index, gonad index and condition index of two commercially important venerid clams (Katelysiaopima and Meretrixmeretrix) of Bhatye estuary, Ratnagiri coast. This study eventually evaluates the physiological fitness or the probable effects of both decline and elevated temperatures on sessile organism. Present study might be useful in understanding the nutritional value of commercially important clams at a different regime of temperature and this information may benefit from bivalve aquaculture as well as fishery point of view.

\section{Materials and Methods}

\section{Animal Collection and Maintenance}

In this study, experimental clams like Katelysiaopima (Gmelin, 1791) and Meretrix meretrix (Linnaeus, 1758) were collected from
Bhatye estuary during low tide with the help of local fishers during April 2010. The collected clams brought to the laboratory, carefully cleaned to remove the adhered fine sediments. All clams were segregated according to their shell length, only mature/average size clams were selected for experimental purpose. The average shell length $(38-42 \mathrm{~mm})$ of $\mathrm{K}$. opima and $(45-50 \mathrm{~mm})$ of M. meretrix has chosen for further experimentation. After segregation and selection, clams were acclimated in plastic container $(3 \times 2 \mathrm{ft})$ for 48 hours at room temperature $\left(30 \pm 1^{\circ} \mathrm{C}\right)$.

\section{Experimental Design}

Healthy clams were exposed to three experimental temperatures $\left(20^{\circ} \mathrm{C}, 25^{\circ} \mathrm{C}\right.$ and $\left.35^{\circ} \mathrm{C}\right)$ along with a control group $\left(30 \pm 1^{\circ} \mathrm{C}\right)$ for 8 days i.e. 192 hours. The $20^{\circ} \mathrm{C}$ and $25^{\circ} \mathrm{C}$ experimental groups were considered as low temperatures, while $35^{\circ} \mathrm{C}$ group treated as a high temperature. The low temperatures $\left(20^{\circ} \mathrm{C}\right.$ and $25^{\circ} \mathrm{C}$ ) were maintained by ice-cold water, while high temperature $\left(35^{\circ} \mathrm{C}\right)$ was controlled by thermostat. In each group of experimental temperatures, thirty (30) clams were exposed. During experimental exposure, water from the container was changed after every six hours. Throughout the experimentation, 38 ppt sea water was used.

\section{Experimental Analysis}

During 192 hours of exposure, five individuals were removed after every 48 hours from experimental sets to assess physiological body indices like hepatopancreas index, gonad index and condition index. These individuals were sacrificed and flesh and shells were separated. The hepatopancreas and gonad were carefully separated from each other, and partially dried by blotting paper to remove the extra water. After blotting, tissues were weighed on monopan electronic digital balance. For drying, the flesh and shells were kept in oven at $60^{\circ} \mathrm{C}$ up to 72 hours to determine the constant dry meat and shell weight. 
In experimental analysis, hepatopancreas index $(\mathrm{HI})$ and Gonadal index (GI) was estimated as described by Giese (1959). The condition index $(\mathrm{Cl})$ was analyzed as suggested by Rainer and Mann (1992). Formulae for HI, GI and $\mathrm{Cl}$ are as follows,

$$
\begin{aligned}
& \text { 1. Hepatopancreas index }(\mathrm{HI})=\frac{\text { Wet weight of hepatopancreas }(\mathrm{g})}{\text { Wet weight of meat }(\mathrm{g})} \times 100 \\
& \text { 2. Gonadal index }(\mathrm{GI})=\frac{\text { Wet weight of gonad }(\mathrm{g})}{\text { Wet weight of meat }(\mathrm{g})} \times 100 \\
& \text { 3. Condition index }(\mathrm{Cl})=\frac{\text { Meat dry weight }(\mathrm{g})}{\text { Dry shell weight }(\mathrm{g})} \times 100
\end{aligned}
$$

\section{Statistical Analysis}

All the results of $\mathrm{HI}, \mathrm{Gl}$ and $\mathrm{Cl}$ were the mean of five separate analyses with \pm SD. One-way ANOVA was used to test the significant difference between means of experimental exposure $\left(20^{\circ} \mathrm{C}, 25^{\circ} \mathrm{C}\right.$ and $\left.35^{\circ} \mathrm{C}\right)$ with the means of control group $\left(30 \pm 1^{\circ} \mathrm{C}\right)$. All statistical difference was accepted at the 0.05 level of significance using the Graph Pad software version 5.04.

\section{Results and Discussion}

In the present investigation, physiological body indices like hepatopancreas index $(\mathrm{HI})$, gonad index $(\mathrm{Gl})$ and condition index $(\mathrm{Cl})$ were studied in two clam species Katelysiaopima and Meretrixmeretrix under short-term exposure of temperatures (Table 1 and 2).In both the clam species, all body indices have been affected significantly after exposure to both increasing and decreasing temperatures.

\section{Hepatopancreas Index (HI)}

After 192 hours of temperature exposure, in $K$. opima the hepatopancreas index $(\mathrm{HI})$ was reduced significantly $(46 \%)$ at high temperature i.e. $35^{\circ} \mathrm{C}$ followed by low temperatures like $20^{\circ} \mathrm{C}(44 \%)$ and $25^{\circ} \mathrm{C}(33 \%)$, while there was $(55 \%, 40 \%$ and $28 \%)$ reduction at $20^{\circ} \mathrm{C}$, $25^{\circ} \mathrm{C}$ and $35^{\circ} \mathrm{Cin} \mathrm{M}$. meretrix species respectively. During exposure of 192 hours, at all temperature ranges $\left(20^{\circ} \mathrm{C}, 25^{\circ} \mathrm{C}\right.$ and $\left.35^{\circ} \mathrm{C}\right)$ the $K$. opima clam showed decline $(p<0.01)$ in $\mathrm{HI}$ at 48 hours, while 96 hours onwards it was declined slowly up to 192 hours. In M. meretrix, at $20^{\circ} \mathrm{C}$, $\mathrm{HI}$ was decreased $(p>0.05)$ at 48 hours, while it was declined $(p<0.05)$ at 96 hours. The significant $(p<0.001)$ decrease in $\mathrm{HI}$ was noticed at 192 hours, but less decline was recorded at 144 hours. At $25^{\circ} \mathrm{C}$, the $\mathrm{HI}$ was declined $(p>0.05)$ at 48,96 hours, 144 hours, while $(p<0.001)$ decline at 192 hours respectively. At high temperature $\left(35^{\circ} \mathrm{C}\right)$, the $\mathrm{HI}$ was successively decreased from 48 to 192 hours of exposure. At 48 hours $(p<0.05)$ and 96 hours $(p<0.01)$ decline was recorded, however, it was reduced $(p<0.001) 192$ hours.

In both the clams, maximum reduction of $\mathrm{HI}$ was recorded particularly at high temperature i.e. $\left(35^{\circ} \mathrm{C}\right)$. Relatively, maximum decline in $\mathrm{HI}$ was observed in $M$. meretrix especially at high temperature however, from $20^{\circ} \mathrm{C}$ and $25^{\circ} \mathrm{C}$ ranges the maximum decline was noted in $K$. opima clam.

Among the environmental factors, temperature is one of the most vital and relevant abiotic factors, which controls all facets of organisms at biological and ecological levels (Heilmayer et al., 2004; Resgalla Jr. et al., 2007). Temperature regulates the extent of species distribution, physiological processes such as feeding, respiration, growth and reproduction (Davenport, 1979; Newell and Branch, 1980; Shumway, 1982). Therefore, in organism adaptation to varying environmental temperature is major challenge in evolutionary adaptation. The adaptation activity is totally relies on the large extent of the organisms ability to compensate metabolic rate under high influence of temperatures at both short-term and long-term exposures (Hochachka and Samero, 2002; Portner, 2002 a, b). According to literature, various body indices like hepatopancreas index, gonad index and condition index has been utilized to assess the physiological measure like reproductive output (Suja and Muthiah, 2009). According to Sokolowicz et al., (2006) the reserved materials and their fluctuation in the hepatopancreas tissue is subjected to gonadal development. 
In this study, after exposure to various temperature ranges the hepatopancreas index $(\mathrm{HI})$ in both the clam species was maximally reduced at high temperature; about $46 \%$ and $55 \%$ decrease was recorded in K. opima and $M$. meretrix respectively. The hepatopancreas functionally plays intermediary role in metabolism and it also acts as a store house for fat bodies (Smith et al., 1975; Bhide et al., 2006).

It is generally accepted that, the nutrients are principally stored in the hepatopancreas tissue or digestive gland. These nutrients are utilized for growth and development, even in reproductive development the hepatopancreas supplies nutrients to gonad for gonadal development. In the present study, after exposure to various temperature maximum reductions in $\mathrm{HI}$ was occurred at high temperature. The metabolic rate increases, consequently the scope for growth reduces at high temperature (Widdows, 1978). In context of increased metabolic rate, clam might be utilized available nutrients to sustain at undesired condition instead of to use for growth and development. Therefore, in order to survive at increased temperature regime, the depletion in $\mathrm{HI}$ was occurred.

Sastry, (1968) reported that, the hepatopancreas index of scallops Aequipectenirradians was depleted at high temperature. He suggested that, the available reserves in scallops have been utilized for maintenance at high temperature regime. Suja and Muthiah (2009) observed considerable difference in digestive index of unfed treatment however, in fed treatment there was no significant change was recorded in $\mathrm{HI}$ at two rearing temperatures $\left(23^{\circ} \mathrm{C}\right.$ and $\left.28^{\circ} \mathrm{C}\right)$. Sastry (1968) suggested that, the digestive gland index was maximum during vegetative and rearing stages.

\section{Gonadal Index (GI)}

Gonad index (GI) also decreased significantly in both the clams when exposed to both low and high temperatures. In K. opima, after 192 hours exposure, maximum decline $(40 \%)$ in $\mathrm{GI}$ was occurred at high temperature like $35^{\circ} \mathrm{C}$ than
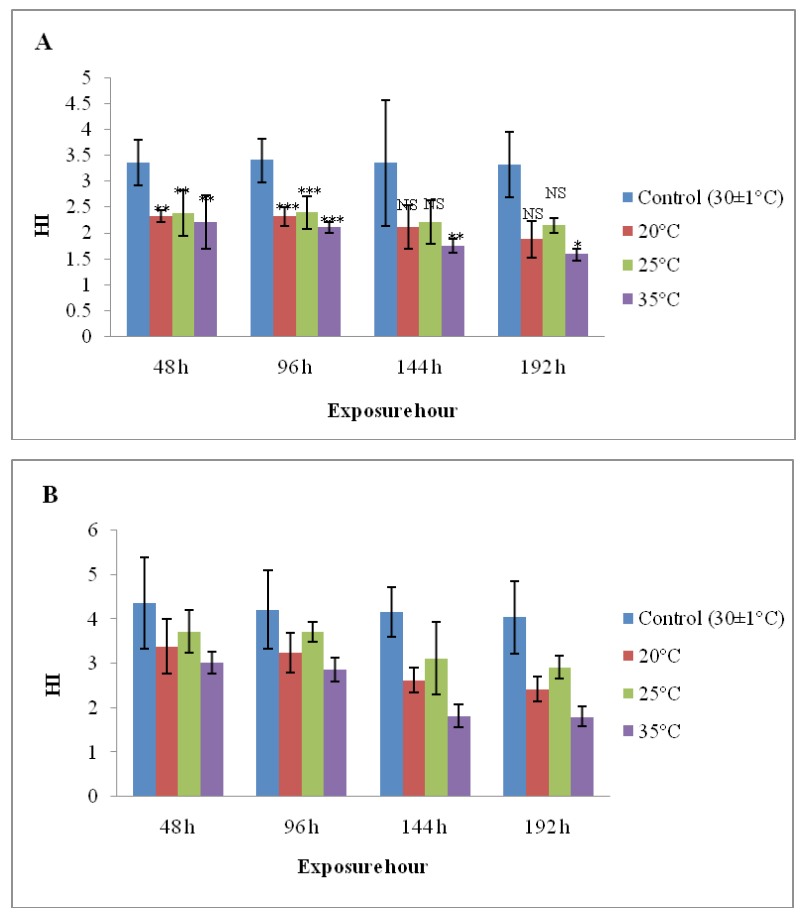

Fig. 1 Effect of temperature on hepatopancreas index $(\mathrm{HI})$ of $(\mathrm{A}) \mathrm{K}$. opima and $(\mathrm{B})$ M. meretrix.

$(27 \%$ and $24 \%)$ at 20 and $25^{\circ} \mathrm{C}$. In M. mere-trix clam also recorded similar trend of decline $\mathrm{GI}$, the maximum decline (41\%) in Gl was noted at high temperature $\left(35^{\circ} \mathrm{C}\right)$ followed by $(36 \%)$ at $20^{\circ} \mathrm{C}$ and $(31 \%)$ at $25^{\circ} \mathrm{C}$ respectively.

During 192 hours of exposure, in K. opima, the $G$ I was declined significantly $(p<0.01)$ in K. opima at 48 hours of exposure, while it was $(p<0.05)$ declined in $M$. meretrix clam. However, 96 hour onwards the GI was declined successively up to 192 hours in both the clams species. Overall, after 192 hours exposure, the highest decline in $\mathrm{Gl}$ was detected in clam $M$. meretrix than $K$. opima.

\section{Condition Index (CI)}

Condition index $(\mathrm{Cl})$ in both the clams has been declined considerably after exposing to both low and high temperatures. Condition index of $K$. opima was decreased significantly at all experimental temperatures after 192 hours of exposure. After $8^{\text {th }}$ day of exposure, the maximum reduction in $\mathrm{Cl}$ was recorded 

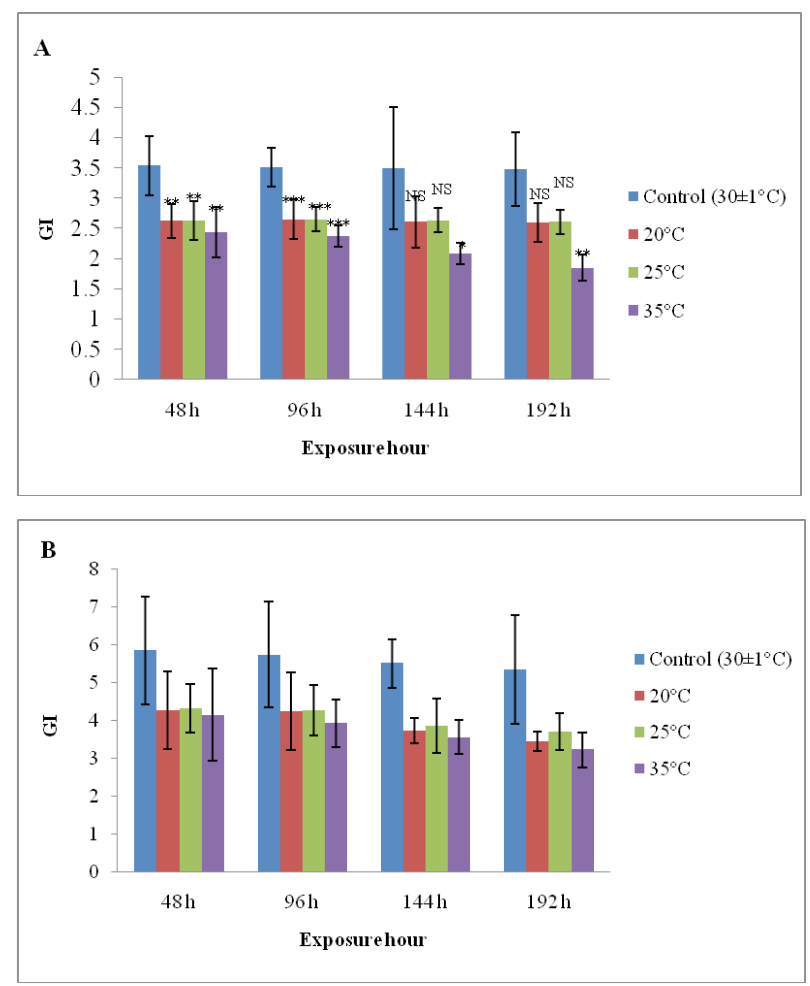

Fig. 2 Effect of temperature on gonadal index (GI) of (A) K. opima and (B) M. meretrix.

at high temperature $\left(35^{\circ} \mathrm{C}\right)$ than lower ranges $\left(20^{\circ} \mathrm{C}\right.$ and $\left.25^{\circ} \mathrm{C}\right)$. At high temperature, $\mathrm{Cl}$ was reduced to $32 \%$, while $26 \%$ and $19 \%$ reduction was recorded at $20^{\circ} \mathrm{C}$ and $25^{\circ} \mathrm{C}$ temperature groups respectively. In this clam, at 20 and $25^{\circ} \mathrm{C}$ the $\mathrm{Cl}$ was declined $(p>0.05)$ during exposure i.e. from $96-144$ hours however, at 48 and 192 hours $\mathrm{Cl}$ was noticed with less $(p<0.05)$ reduction. In case of high temperature $\left(35^{\circ} \mathrm{C}\right), \mathrm{Cl}$ was slightly $(p<0.05)$ reduced from 96 to 192 hours, but significant $(p<0.01)$ reduction was noticed at 48 hours.

In $M$. meretrix clam maximum reduction in $\mathrm{Cl}$ was noticed at high temperature than low temperatures. After $8^{\text {th }}$ day of exposure, 39\% reduction was recorded at $35^{\circ} \mathrm{C}$, while at $20^{\circ} \mathrm{C}$, $36 \%$ reduction and at $25^{\circ} \mathrm{C}, 17 \%$ reduction was recorded respectively. In all temperature ranges, $\mathrm{Cl}$ was suddenly declined at 48 hours however, later i.e. from 96 to 192 hours, there was slow decline in Cl. During 192 hours exposure of both high and low temperatures, the $\mathrm{Cl}$
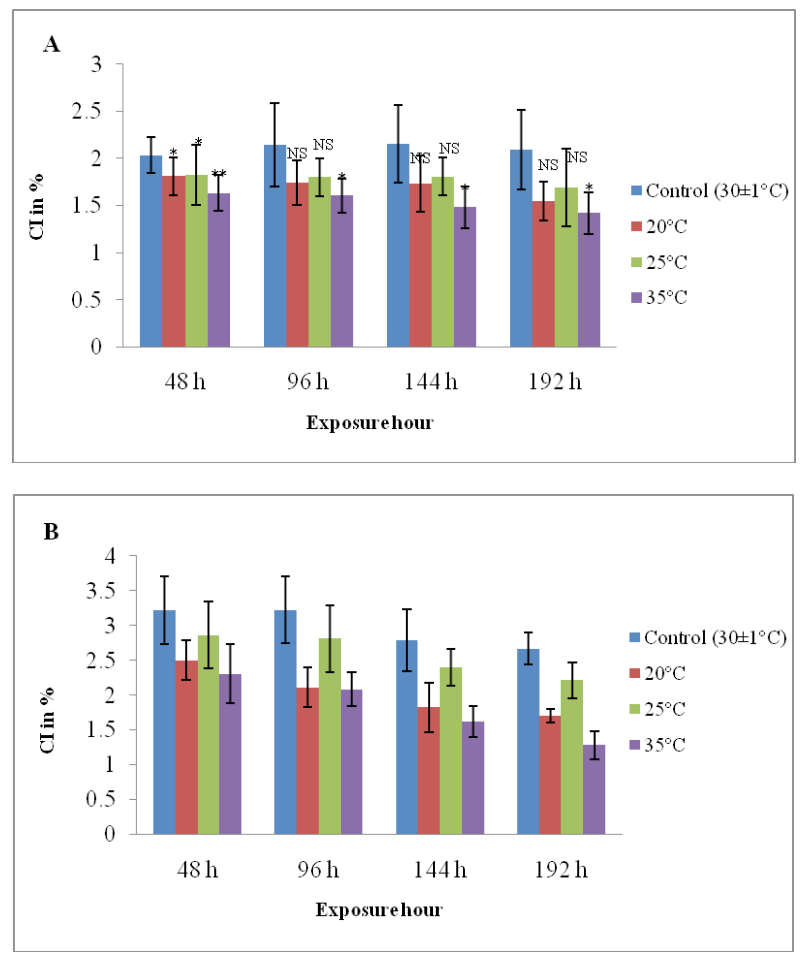

Fig. 3 Effect of temperature on condition index (CI) of (A) K. opima and (B) M. meretrix

All results are the mean of five observations and bar indicates the \pm standard deviations.

$(p<0.001)={ }^{* * *},(p<0.01)={ }^{* *},(p<0.05)={ }^{*}$ and $(p>0.05)=$ NS.

was considerably declined. At high temperature $\left(35^{\circ} \mathrm{C}\right)$, the $\mathrm{Cl}$ was declined slightly $(p<0.05)$ at 48 hours, however significantly $(p<0.01)$ at $96-120$ hour and $(p<0.001)$ declined at $144-$ 192 hours respectively. At low temperature like $\left(20^{\circ} \mathrm{C}\right)$, the $\mathrm{Cl}$ was non-significantly $(p>0.05)$ declined at 48 hours, while $(p<0.01)$ at 96,144 hours and $(p<0.001)$ reduction was recorded at 192 hours respectively. However, at $25^{\circ} \mathrm{C}$ the $\mathrm{Cl}$ was decreased ( $p>0.05$ ) from 48-144 hour, while $(p<0.05)$ reduction at 192 hours.

In recent past, several authors well documented the studies on physiological body indices in bivalves and they have reported a strict relationship between the condition index increment and the gonadal development (Hamida et al., 2004; Ojea et al., 2004; Mladineo et al., 2007). Similarly, Abraham (1996) and Suja and Muthiah 
Table 1 Effect of temperature on $\mathrm{HI}, \mathrm{Gl}$ and $\mathrm{Cl}$ of Katleysia opima clam.

\begin{tabular}{|c|c|c|c|c|c|c|c|c|c|c|c|c|}
\hline \multirow{3}{*}{$\begin{array}{l}\text { Exposure } \\
\text { hours }\end{array}$} & \multicolumn{12}{|c|}{ Temperature ranges } \\
\hline & \multicolumn{3}{|c|}{ Control $\left(30 \pm 1^{\circ} \mathrm{C}\right)$} & \multicolumn{3}{|c|}{$20^{\circ} \mathrm{C}$} & \multicolumn{3}{|c|}{$25^{\circ} \mathrm{C}$} & \multicolumn{3}{|c|}{$35^{\circ} \mathrm{C}$} \\
\hline & HI & GI & $\mathrm{Cl}$ & $\mathrm{HI}$ & GI & $\mathrm{Cl}$ & $\mathrm{HI}$ & GI & $\mathrm{Cl}$ & $\mathrm{HI}$ & GI & $\mathrm{Cl}$ \\
\hline $48 \mathrm{~h}$ & $\begin{array}{c}3.36 \\
\pm 0.44\end{array}$ & $\begin{array}{c}3.54 \\
\pm 0.48\end{array}$ & $\begin{array}{c}2.03 \\
\pm 0.18\end{array}$ & $\begin{array}{c}2.32 \\
\pm 0.11^{\star * \star}\end{array}$ & $\begin{array}{c}2.62 \\
\pm 0.28^{\star *}\end{array}$ & $\begin{array}{c}1.81 \\
\pm 0.10^{*}\end{array}$ & $\begin{array}{c}2.38 \\
\pm 0.44^{* * \star}\end{array}$ & $\begin{array}{c}2.62 \\
\pm 0.31^{\text {** }}\end{array}$ & $\begin{array}{c}1.82 \\
\pm 0.31^{*}\end{array}$ & $\begin{array}{c}2.20 \\
\pm 0.52^{\star * *}\end{array}$ & $\begin{array}{c}2.44 \\
\pm 0.42^{\text {** }}\end{array}$ & $\begin{array}{c}1.632 \\
\pm 0.388^{* *}\end{array}$ \\
\hline $96 \mathrm{~h}$ & $\begin{array}{c}3.40 \\
\pm 0.42\end{array}$ & $\begin{array}{c}3.51 \\
\pm 0.31\end{array}$ & $\begin{array}{c}2.14 \\
\pm 0.44\end{array}$ & $\begin{array}{c}2.31 \\
\pm 0.18^{\star * *}\end{array}$ & $\begin{array}{c}2.65 \\
\pm 0.33^{* * *}\end{array}$ & $\begin{array}{c}1.74 \\
\pm 0.33 \mathrm{NS}\end{array}$ & $\begin{array}{c}2.38 \\
\pm 0.31^{\star \star *}\end{array}$ & $\begin{array}{c}2.65 \\
\pm 0.20^{* * *}\end{array}$ & $\begin{array}{c}1.80 \\
\pm 0.20 \mathrm{NS}\end{array}$ & $\begin{array}{c}2.10 \\
0.11^{\star \star \star}\end{array}$ & $\begin{array}{c}2.37 \\
\pm 0.18^{* * *}\end{array}$ & $\begin{array}{c}1.606 \\
\pm 0.180^{\star}\end{array}$ \\
\hline $144 \mathrm{~h}$ & $\begin{array}{c}3.34 \\
\pm 1.42\end{array}$ & $\begin{array}{c}3.48 \\
\pm 1.01\end{array}$ & $\begin{array}{c}2.15 \\
\pm 0.41\end{array}$ & $\begin{array}{c}2.11 \\
\pm 0.42 \mathrm{NS}\end{array}$ & $\begin{array}{c}2.60 \\
\pm 0.42 \mathrm{NS}\end{array}$ & $\begin{array}{c}1.72 \\
\pm 0.30 \mathrm{NS}\end{array}$ & $\begin{array}{c}2.21 \\
\pm 0.42 \mathrm{NS}\end{array}$ & $\begin{array}{c}2.60 \\
\pm 0.20 \mathrm{NS}\end{array}$ & $\begin{array}{c}1.80 \\
\pm 0.20 \mathrm{NS}\end{array}$ & $\begin{array}{c}1.75 \\
\pm 0.14 \text { * }\end{array}$ & $\begin{array}{c}2.08 \\
\pm 0.18^{\text {** }}\end{array}$ & $\begin{array}{c}1.480 \\
\pm 0.220 \text { * }\end{array}$ \\
\hline $192 \mathrm{~h}$ & $\begin{array}{c}3.32 \\
\pm 0.62\end{array}$ & $\begin{array}{c}3.48 \\
\pm 0.60\end{array}$ & $\begin{array}{c}2.08 \\
\pm 0.42\end{array}$ & $\begin{array}{c}1.87 \\
\pm 0.36^{\star \star *}\end{array}$ & $\begin{array}{c}2.59 \\
\pm 0.31^{\text {** }}\end{array}$ & $\begin{array}{c}1.54 \\
\pm 0.20 \mathrm{NS}\end{array}$ & $\begin{array}{c}2.14 \\
\pm 0.14^{\star * \star}\end{array}$ & $\begin{array}{c}2.60 \\
\pm 0.20^{\text {** }}\end{array}$ & $\begin{array}{c}1.69 \\
\pm 0.41 \mathrm{NS}\end{array}$ & $\begin{array}{c}1.58 \\
\pm 0.11^{\star \star *}\end{array}$ & $\begin{array}{c}1.85 \\
\pm 0.22^{\star \star \star}\end{array}$ & $\begin{array}{c}1.42 \\
\pm 0.220^{*}\end{array}$ \\
\hline
\end{tabular}

$\mathrm{HI}=$ Hepatopancreas index, $\mathrm{Gl}=$ Gonadal index, $\mathrm{Cl}=$ Condition index. All results are the mean of five observations with $\pm \mathrm{SD}$. $(p<0.001)={ }^{* * *},(p<0.01)={ }^{* *},(p<0.05)={ }^{*}$ and $(p>0.05)=$ NS.

Table 2 Effect of temperature on $\mathrm{HI}, \mathrm{Gl}$ and $\mathrm{Cl}$ of Meretrixmeretrix clam.

\begin{tabular}{|c|c|c|c|c|c|c|c|c|c|c|c|c|}
\hline \multirow{3}{*}{$\begin{array}{l}\text { Exposure } \\
\text { hours }\end{array}$} & \multicolumn{12}{|c|}{ Temperature ranges } \\
\hline & \multicolumn{3}{|c|}{ Control $\left(30 \pm 1^{\circ} \mathrm{C}\right)$} & \multicolumn{3}{|c|}{$20^{\circ} \mathrm{C}$} & \multicolumn{3}{|c|}{$25^{\circ} \mathrm{C}$} & \multicolumn{3}{|c|}{$35^{\circ} \mathrm{C}$} \\
\hline & $\mathrm{HI}$ & GI & $\mathrm{Cl}$ & $\mathrm{HI}$ & GI & $\mathrm{Cl}$ & $\mathrm{HI}$ & GI & $\mathrm{Cl}$ & $\mathrm{HI}$ & GI & $\mathrm{Cl}$ \\
\hline $48 \mathrm{~h}$ & $\begin{array}{r}4.36 \\
\pm 1.03 \\
\end{array}$ & $\begin{array}{r}5.83 \\
\pm 1.42 \\
\end{array}$ & $\begin{array}{c}3.21 \\
\pm 0.48 \\
\end{array}$ & $\begin{array}{c}3.38 \\
\pm 0.62 \mathrm{NS} \\
\end{array}$ & $\begin{array}{r}4.26 \\
\pm 1.02^{*} \\
\end{array}$ & $\begin{array}{c}2.49 \\
\pm 0.28 \mathrm{NS} \\
\end{array}$ & $\begin{array}{c}3.71 \\
\pm 0.47 \mathrm{NS} \\
\end{array}$ & $\begin{array}{r}4.30 \\
\pm 0.64^{*} \\
\end{array}$ & $\begin{array}{c}2.86 \\
\pm 0.48 \mathrm{NS} \\
\end{array}$ & $\begin{array}{r}3.02 \\
\pm 0.24^{*} \\
\end{array}$ & $\begin{array}{c}4.14 \\
\pm 1.22^{*} \\
\end{array}$ & $\begin{array}{r}2.30 \\
\pm 0.42^{*} \\
\end{array}$ \\
\hline $96 \mathrm{~h}$ & $\begin{array}{c}4.21 \\
\pm 0.88\end{array}$ & $\begin{array}{c}5.73 \\
\pm 1.40\end{array}$ & $\begin{array}{c}3.22 \\
\pm 0.47\end{array}$ & $\begin{array}{c}3.24 \\
\pm 0.44^{*}\end{array}$ & \begin{tabular}{|c|}
4.23 \\
$\pm 1.03 \mathrm{NS}$ \\
\end{tabular} & $\begin{array}{c}2.11 \\
\pm 0.28^{* *}\end{array}$ & \begin{tabular}{|c|}
3.70 \\
$\pm 0.22 \mathrm{NS}$
\end{tabular} & $\begin{array}{c}4.26 \\
\pm 0.66 \mathrm{NS}\end{array}$ & $\begin{array}{c}2.81 \\
\pm 0.48 \mathrm{NS} \\
\end{array}$ & $\begin{array}{c}2.86 \\
\pm 0.26^{* *}\end{array}$ & $\begin{array}{c}3.92 \\
\pm 0.62^{*}\end{array}$ & $\begin{array}{c}2.08 \\
\pm 0.24^{* *}\end{array}$ \\
\hline $144 \mathrm{~h}$ & $\begin{array}{c}4.15 \\
\pm 0.56 \\
\end{array}$ & $\begin{array}{c}5.50 \\
\pm 0.64\end{array}$ & $\begin{array}{c}2.99 \\
\pm 0.44\end{array}$ & $\begin{array}{c}2.62 \\
\pm 0.28^{* *}\end{array}$ & $\begin{array}{c}3.72 \\
\pm 0.33^{\star * *} \\
\end{array}$ & $\begin{array}{c}1.82 \\
\pm 0.35^{\star *}\end{array}$ & $\begin{array}{c}3.11 \\
\pm 0.82^{*} \\
\end{array}$ & $\begin{array}{c}3.85 \\
\pm 0.72^{* *}\end{array}$ & \begin{tabular}{|c|}
2.40 \\
$\pm 0.26 \mathrm{NS}$ \\
\end{tabular} & $\begin{array}{c}1.82 \\
\pm 0.26^{* * *} \\
\end{array}$ & $\begin{array}{c}3.55 \\
\pm 0.44^{* * *}\end{array}$ & $\begin{array}{c}1.86 \\
\pm 0.22^{* * *}\end{array}$ \\
\hline $192 \mathrm{~h}$ & $\begin{array}{c}4.04 \\
\pm 0.82\end{array}$ & $\begin{array}{c}5.33 \\
\pm 1.44\end{array}$ & $\begin{array}{c}2.90 \\
\pm 0.23\end{array}$ & $\begin{array}{c}2.42 \\
\pm 0.28^{* * *}\end{array}$ & $\begin{array}{c}3.44 \\
\pm 0.26^{\text {** }}\end{array}$ & $\begin{array}{c}1.70 \\
\pm 0.10^{\star * *}\end{array}$ & $\begin{array}{c}2.92 \\
\pm 0.26^{* *}\end{array}$ & $\begin{array}{c}3.70 \\
\pm 0.48^{*}\end{array}$ & $\begin{array}{c}2.21 \\
\pm 0.26^{*}\end{array}$ & $\begin{array}{c}1.80 \\
\pm 0.22^{\star * *}\end{array}$ & $\begin{array}{c}3.22 \\
\pm 0.46^{* *}\end{array}$ & $\begin{array}{c}1.79 \\
\pm 0.20^{\text {*** }}\end{array}$ \\
\hline
\end{tabular}

$\mathrm{HI}=$ Hepatopancreas index, $\mathrm{Gl}=$ Gonadal index, $\mathrm{Cl}=$ Condition index. All results are the mean of five observations with $\pm \mathrm{SD}$. $(p<0.001)={ }^{* * *},(p<0.01)={ }^{* *},(p<0.05)={ }^{*}$ and $(p>0.05)=N S$.

(2009) observed direct relationship between condition index and gonadosomatic index.

In the present study, both clam species showed considerable decrease in condition index $(\mathrm{Cl})$ at high temperature. It clearly indicates that, the $\mathrm{Cl}$ of clams is closely associated with the gonad index. At stress condition, there was a limitation of both oxygen and food hence, the organism suppressed their oxygen consumption and ceasing all activity in order to conserve the energy and maintenance at undesired environment (Laing et al., 1987). The probable reason for declining the gonadal and condition index might be the availability of food at different temperature regime. Because insufficient quantity of nutrients may suppressed the gonadal development and maturation (Suja and Muthiah, 2009) ultimately the physiological condition of clams may affected. Recently, Yap and Al-Barwani, (2012) recorded decline in condition index when mussel Pernaviridis subjected to stress condition.

Finally we concluded that, the physiological measures like hepatopancreas index, gonadal index and condition index amongst both the clam species were significantly declined when exposed to three experimental temperatures $(20$, 25 and $35^{\circ} \mathrm{C}$ ). At all experimental temperatures, 
the physiological body indices were declined significantly however, highest decline in body indices has been noticed at high temperature $\left(35^{\circ} \mathrm{C}\right)$ followed by $20^{\circ} \mathrm{C}$ and $25^{\circ} \mathrm{C}$. Relatively, maximum decline in the indices was recorded in $M$. meretrix species than K. opima. Based on this observation, it assumed that, both the clam species are very sensitive to changing temperature particularly to high temperature $\left(35^{\circ} \mathrm{C}\right)$ and comparatively $M$. meretrix species is more sensitive towards temperature change than $K$. opima.

\section{Acknowledgement}

The authors are very thankful to Retd. Prof. U. H. Mane, Director, Centre for Coastal and Marine Biodiversity, Bhatye, Ratnagiri, for his valuable suggestion and guidance throughout research work.

\section{References}

Abraham, K.J. (1996) Studies on gonad index of edible oyster Crassostreamadrasensis (Preston). M.Sc. Thesis, CIFE, 61.

Bayne, B.L. (1984) Aspect of reproduction in bivalve molluscs. Adv. Invert. Repro., 3, 357-366.

Bhide, M., Gupta, A., Khan, M.,Dubey, U., Thakur, P., Nema, P. and Jain, S.(2006) Morphological and biochemical studies on the different developmental stages of a freshwater snail, Lymnaeastagnalis(Lymnaeidae) after treatment with some pesticides. J. Environ. Biol., 27, 359-366.

Celik, M.Y., Karayucel, S., Karayucel,I., Ozturk, R. and Eyuboglu, B. (2012) Meat yield, condition index and biochemical composition of mussels (Mytilusgalloprovincialis Lamarck, 1819) in Sinop, South of the Black Sea. J. Aqu. Food Prod. Tech., 21, 198-205.

Davenport, J. (1979) Is Mytilusedulis a short-term osmoregulator. Comp. Biochem. Physiol., 64, 91-95.

Delgado, M. and Perez-Camacho, A. (2007) Comparative study of gonadal development of Ruditapesphilippinarum (Adam and Reeve) and Ruditapesdecussatus (L.) (Mollusca: Bivalvia): Influence of temperature. Sci. Mar., 71, 471-484.

Delgado, M., Perez-Camacho, A., Labarta, U. and Fernandez-Reiriz, M.J. (2004) The role of lipids in the gonadal development of the clam Ruditapesdecussatus (L.). Aquaculture., 241,395-411.

Flores-Vergara, C., Corder-Esquivel, B., Ceró-Ortiz, A.N. and Arrendondo-Vega, B.O. (2004) Combined effects of temperature and diet growth on biochemical composition of the Pacific oyster Crassostreagigas (Thumberg) spat. Aqua. Res., 35, 1131-1140.

Galap, C., Leboulenger, F. and Grillot, J.P.(1997) Seasonal variation in biochemical constituents during the reproductive cycle of the female dog cockle Glycymerisglycymeris. Mar. Biol., 129, 625-634.

Giese, A.C. (1959) Comparatively physiology: Annual reproductive cycles of marine Invertebrates. Ann. Rev. Physiol., 21, 547-576.

Gillooly, J.F., Brown, J.H., West, G.B., Savage, V.M. and Charnov, E.L.(2001) Effects of size and temperature on metabolic rate. Science., 293, 2248-2251.

Hamida, L., Medhiouband, M.N., Cochard, J.C., Rhomdhane, M.S. and Le Pennec,, M. (2004) E tude comparative du cycle de reproduction de lapalourde Ruditapes decussatusen milieu naturel (sudTunisie) etcontrole (e closerie). Cahiers de Biol. Mar., 45, 291-303.

Heilmayer, O., Brey, T., Storch, D., Mackensen, A. and Arntz, A.E. (2004) Population dynamics and metabolism of Aequipectenopercularis (L.) from the western English Channel (Roscoff, France). J. Sea Res., 52, 33-44.

Hochachka, P. M. and Somero, G. N. (2002) Biochemical Adaptation. Oxford: Princeton University Press.

Honkoop, P.J.C. and Meer Vander, J. (1997) Reproductive output of Macomabalthica populations in relation to winter-temperature and intertidal-height mediated changes of body mass. Mar. Ecol. Prog. Ser., 149, 155-162.

Laing, I., Utting, S. D. and Kilada, R.W.S. (1987) Interactive effect of diet and temperature on the growth of juvenile clams. J. Exp. Mar. Biol. Ecol., 113, 23-38.

Lannig, G., Eilers, S., Portne, H.O.,Sokolova, I.M. and Bock, C.(2010) Impact of ocean acidification on energy metabolism of Oyster, Crassostreagigas changes in metabolic pathways and thermal response. Mar. Drugs., 8, 2318-2339.

Li, Q., Yang,L., Ke, Q. and Kong, L.(2011)Gametogenic cycle and biochemical composition of the calm Mactrachinensis (Mollusca: Bivalvia): Implication for aquaculture and wild stock management. Mar. Biol. Res, 7, 407-415.

Li, Y., Qin,J.G, Li, X. and Benkendorff, K.(2009) Monthly variations of condition index, energy reserves and antibacterial activity in pacific oysters, Crassostreagigas, in Stansbury (South Australia). Aquaculture., 286, 64-71.

Lomovasky, B.J., Gabriela, M. and Jorge, C.(2004) Seasonal changes in biochemical of the clam, Eurhomaleaexalbida, from the Beagle channel, Argentina. J. Shellfish Res., 23, 81-88. 
Mac Donald, B.A. and Thompson, R.J. (1985) Influence of temperature and food availability on the ecological energetics of the giant scallop Placopectenmagellanicus. I. Growth rates of shell and somatic tissue. Mar. Ecol. Prog. Ser., 25, 279-294.

Martinez, G. and Perez, H.(2003) Effect of different temperature regimes on reproductive conditioning in the scallop Argopectenpurpuratus. Aquaculture., 228, 153-167.

Martínez-Porchas, M., Hernandez-Rodríguez, M. and Buckle-Ramírez, L. F. (2009) Thermal behavior of the Pacific sardine (Sardinopssagax) acclimated to different thermal cycles. J. Thermal Biol., 34, 372-376.

Matias, D., Joaquim, S. L. and Massapina, C. (2009) Effect of geographic origin, temperature and timing of broodstock collection on conditioning, spawning success and larval viability of Ruditapes decussates (Linne, 1758). Aqua. Inter., 17, 257-271.

Mladineo, I., Peharda, M., Orhanovic, S., Bolotin, J., Pavela-Vrancic, M. and Treursic, B. (2007) The reproductive cycle, condition index and biochemical composition of the horse-bearded mussel Modiolusbarbatus, Helgol. Mar. Res., 61, 183-192.

Newell, R.C. and Branch, G.M. (1980) The influence of temperature on the maintenance of metabolic energy balance in marine invertebrates. Adv. Mar. Biol., 17, 329-396.

Newell, R.I.E., Hilbish,T.J., Koehn, R.K. and Newell, C.J. (1982) Temporal variation in the reproductive cycle of Mytilusedulis (L.) (Bivalvia: Mytilidae) from localities on the east coast of United States. Biol. Bull., 162, 299-310.

Ojea, J., Pazos, A.J., Martinez, D., Novoa, S., Sanchez, J.L. and Abad, M. (2004) Seasonal variation in weight and biochemical composition of the tissues of Ruditapes decussatesin relation to the gametogenic cycle. Aquaculture., 238, 451-468.

Orban, E., Di Lena, G., Nevigato, T., Casini, I., Caproni, R., Santorini, G. and Giulini, G.(2006) Nutritional and commercial quality of the striped venus clam, Chamelea gallina, from the Adriatic sea. Food Chem.,101, 1063-1070.

Portner, H.O. (2002a) Climate variations and the physiological basis of temperature dependent biogeography: systemic to molecular hierarchy of thermal tolerance in animals. Com. Bioch. Physiol., 132A, 739-761.

Portner, H.O. (2002b) Physiological basis of temperature dependent biogeography: tradeoffs in muscle design and performance in polar ectotherms. J. Exp. Biol., 205, 2217-2230.
Portner, H.O. (2010) Oxygen and capacity limitation of thermal tolerance: a matrix for integrating climate related stressors in marine ecosystems. J. Exp. Biol., 213, 881-893.

Rainer, J.S. and Mann, R. (1992) A comparison of methods calculating condition index in eastern oysters, Crassostreavirginica (Gmelin, 1791). J. Shellfish Res., 11, 55-58.

Resgalla, Jr. C., Brasil, E.S., Laitano, K.S. and Reis Filho, R.W. (2007) Physiology of the mussel Pernaperna (Mytilidae) in Southern Brazil. Aquaculture., 270, 464-474.

Robert, R., Chretiennot- Dinet, M.J., Kaas, R., MartinJezequel, V., Moal, J., Le Coz, J.R., Nicolas, E., Bernard, Connan J.P., Le Dean, L., Gourrierec, G., Leroy, B. and Quere, C. (2003) Amelioration des productions phytoplanctoniquesenecloserie de mollusques: caracterisationdes microalgues fourrage. Report Ifremer DRV/RA/RST/LPI/20042005, pp. 150.

Sastry, A.N. (1968) Relationship among food, temperature and gonad development of the bay scallop, Aequipecten irradians Lamarck. Physiol. Ecol., 41, 44-53.

Shriver, A.C., Carmichael, R.H. and Daliela, I.(2002) Growth, condition, reproductive potential, and mortality of bay scallops, Argopecten irradians, in response to eutrophic- driven changes in food resources. J. Exp. Mar. Biol. Ecol., 279, 21-40.

Shumway, S.E. (1982) Oxygen consumption in oysters: an overview. Mar. Biol. Lett., 3, 1-23.

Smith, K.L. Jr, Harrison, G.T., Rowe, G.T. and Clifford, C.H.(1975) Respiration and chemical composition of Pleuroncodesplanipes (Decapoda: Galatheidae): energetic significance in an upwelling system. J. Fish. Res. Board Canada., 32, 1607-1612.

Sokolowicz, C.C., Bond-Buckup, G. and Buckup, L. (2006) Dynamics of gonadal development of Aeglaplatensis Schmitt (Decapoda, Anomura, Aeglidae). Rev. Brasileira de Zool., 23, 1153-1158.

Suja, N and Muthiah, P. (2009) Effect of starvation and temperature on gonad development of baby clam, Marcia opima (Gmelin). J. Mar. Biol. Asso. India., 51, 21-25.

Widdows, J. (1978) Physiological indices of stress in Mytilusedulis. J. Mar. Biol. Asso. UK., 58, 125-142.

Yap, C.K. and AL- Barwani, S.M. (2012) A Comparative Study of Condition Indices and Heavy metals in Pernaviridis populations at Sebatu and Muar, Peninsular Malaysia. Sains Malaysiana., 41, 1063-1069. 